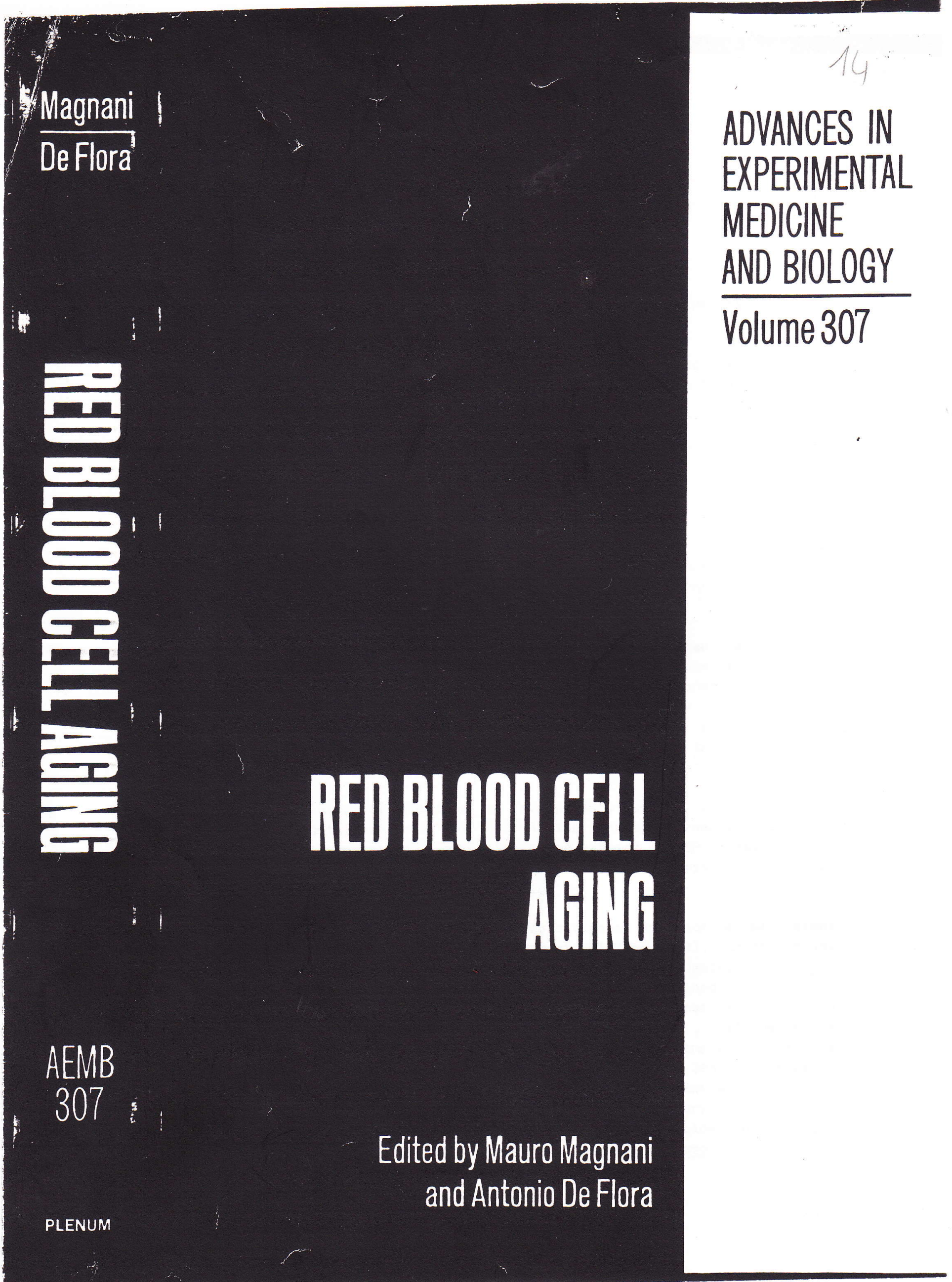




\title{
ACYLPHOSPHATASE AND CALCIUM TRANSPORT ACROSS ERYTHROCYTE MEMBRANE
}

\author{
Chiara Nediani, Gianfranco Liguri, Niccolò Taddei, \\ Elena Marchetti, Giampietro Ramponi and Paolo Nassi \\ Dipartimento di Scienze Biochimiche \\ Università di Firenze, Firenze, Italy
}

\section{INTRODUCTION}

Acylphosphatase is a widespread cytosolic enzyme that catalyzes the hydrolysis of carboxylphosphate bond compounds. Among natural acylphosphates hydrolyzed by the enzyme are 3-phosphoglyceroylphosphate (1) carbamoylphosphate (2), succinoylphosphate (3).

In mammalian tissues acylphosphatase exists in two isoenzymatic forms: one is prevalent in skeletal muscle (4-7), the other in red blood cells (RBCs) (8). The two isoenzymes are very small basic proteins with the same number of aminoacids but differing significantly in primary structure. They exhibit similar substrate specificity and kinetic properties, except that erythrocyte isoenzyme appears to have a higher catalytic power.

The physiological function of acylphosphatase is still debated. It has been postulated that, by hydrolyzing 3-phosphoglyceroylphosphate, acylphosphatase may hasten glycolysis at the expence of ATP formation, when the rate of this pathway is limited by low concentrations of inorganic phosphate and ATP.

In a recent research project we investigated acylphosphatase content and activity during the human erythrocyte lifespan (9). In this study erythrocytes were age-fractioned by isopicnic centrifugation in Percoll density gradients. Acylphosphatase content was determined by a noncompetitive enzyme-linked immunoadsorbent assay (ELISA) carried out with policlonal antierythrocyte acylphosphatase antibodies (10). Acylphosphatase activity was measured by a continuous optical test with benzoylphosphate as substrate based on the difference in absorbance at $283 \mathrm{~nm}$ between benzoylphosphate and benzoate (11). Acylphosphatase content and activity rose with ageing of red blood cells. Maximum values occurred in mature erythrocytes and these values decreased slightly in the older cells (Fig. 1). This singular behaviour may be attributed to a de-novo synthesis of 


\title{
ACYLPHOSPHATASE AND CALCIUM TRANSPORT ACROSS ERYTHROCYTE MEMBRANE
}

\author{
Chiara Nediani, Gianfranco Liguri, Niccolò Taddei, \\ Elena Marchetti, Giampietro Ramponi and Paolo Nassi \\ Dipartimento di Scienze Biochimiche \\ Università di Firenze, Firenze, Italy
}

\section{INTRODUCTION}

Acylphosphatase is a widespread cytosolic enzyme that catalyzes the hydrolysis of carboxylphosphate bond compounds. Among natural acylphosphates hydrolyzed by the enzyme are 3-phosphoglyceroylphosphate (1) carbamoylphosphate (2), succinoylphosphate (3).

In mammalian tissues acylphosphatase exists in two isoenzymatic forms: one is prevalent in skeletal muscle (4-7), the other in red blood cells (RBCs) (8). The two isoenzymes are very small basic proteins with the same number of aminoacids but differing significantly in primary structure. They exhibit similar substrate specificity and kinetic properties, except that erythrocyte isoenzyme appears to have a higher catalytic power.

The physiological function of acylphosphatase is still debated. It has been postulated that, by hydrolyzing 3-phosphoglyceroylphosphate, acylphosphatase may hasten glycolysis at the expence of ATP formation, when the rate of this pathway is limited by low concentrations of inorganic phosphate and ATP.

In a recent research project we investigated acylphosphatase content and activity during the human erythrocyte lifespan (9). In this study erythrocytes were age-fractioned by isopicnic centrifugation in Percoll density gradients. Acylphosphatase content was determined by a noncompetitive enzyme-linked immunoadsorbent assay (ELISA) carried out with policlonal antierythrocyte acylphosphatase antibodies (10). Acylphosphatase activity was measured by a continuous optical test with benzoylphosphate as substrate based on the difference in absorbance at $283 \mathrm{~nm}$ between benzoylphosphate and benzoate (11). Acylphosphatase content and activity rose with ageing of red blood cells. Maximum values occurred in mature erythrocytes and these values decreased slightly in the older cells (Fig. 1). This singular behaviour may be attributed to a de-novo synthesis of 
the enzyme during reticulocyte stage and its storage, virtually unaffected, in mature erythrocytes. As glycolysis is the only energy source of the red cell, the increase of acylphosphatase during erythrocyte maturation and its persistence at high levels in old cells could contribute to a progressive reduction of the energetic yield of glycolysis due to an uncoupling effect of this enzyme produced by the hydrolysis of the carboxylphosphate bond of 3-phosphoglyceroylphosphate.

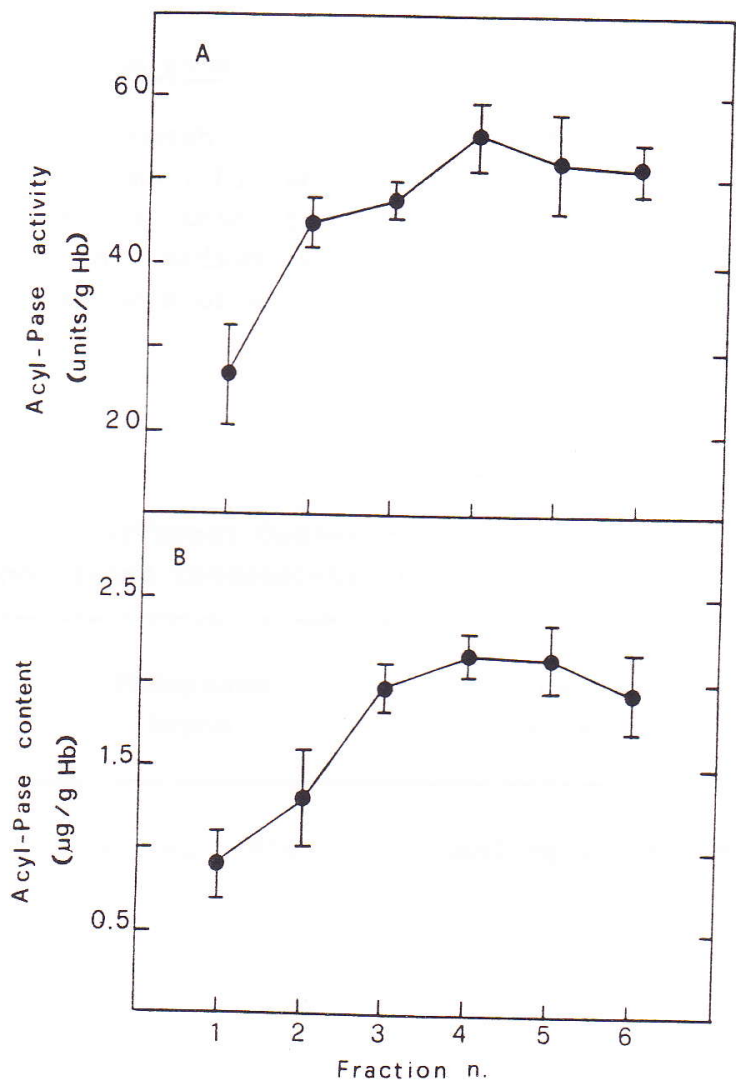

Fig. 1. Acylphosphatase (Acyl--Pase) levels in six classes of increasing age erythrocytes. Each point represents the mean \pm S.D. of six determinations. (A) acylphosphatase activity (units/g hemoglobin). (B) acylphosphatase content ( $\mu \mathrm{g} / \mathrm{g}$ hemoglobin). The changes observed in fractions 2 vs. 1,3 vs. 2 and 4 vs. 3 were statistically significant $(p<0.05)$.

Acylphosphatase, however, might affect in other was the energy metabolism of erythrocytes. Human red blood cell membrane has a $\mathrm{Ca}^{2+}$-ATPase system that pumps $\mathrm{Ca}^{2+}$ ions out of the cell coupling calcium transport to ATP hydrolysis, the latter proceeding through a series of reactions that involve the $\mathrm{Ca}^{2+}$ dependent formation of an acylphosphorylated intermediate. It is well known that human $\mathrm{RBC} \mathrm{Ca}{ }^{2+}$-ATPase is activated by calmodulin and that this effect is associated with an increased rate in phosphorylated intermediate formation (12). Human RBCs, however, seems to contain other soluble (13) and particulate factors (14) that can modulate $\mathrm{Ca}^{2+}-\mathrm{ATPase}$ activity. 
We supposed that RBC acylphosphatase, on the basis of a potential hydrolytic effect on the acylphosphorylated intermediate, might represent an additional modulator of $\mathrm{Ca}^{2+}$-ATPase that would effect both ATP hydrolysis and calcium transport. In other words, the efficiency of erythrocyte membrane $\mathrm{Ca}^{2+}$ pump. The studies that we conducted to examine this hypothesis are here reported.

\section{EXPERIMENTAL}

Effect of acylphosphatase on phosphorylated intermediate from RBC membranes

RBC membranes were phosphorylated according to Luthra et al.(15) and the level of phosphoenzyme (EP) was taken as the difference between the amount of $32 \mathrm{P}$ incorporated into the membrane protein in a medium with $\mathrm{Ca}$ and in an identical medium without $\mathrm{Ca}^{2+}$. Labeled membranes were incubated with varying amounts of acylphosphatase from 2 to 10 units per mg membrane protein.

Table 1. Effect of Different Concentration of Acylphosphatase on Phosphorylated Intemediate from RBC Membranes

\begin{tabular}{|c|c|c|}
\hline Sample & $\begin{array}{c}\text { Phosphate } \\
\text { bound }\end{array}$ & $\begin{array}{r}\text { Phosphate } \\
\text { released }\end{array}$ \\
\hline
\end{tabular}

$\mathrm{pmol} / \mathrm{mg}$ protein $\quad \mathrm{pmol} / \mathrm{mg}$ protein/min

Labeled

membranes

$1.81 \pm 0.07$

Control for

spontaneous

hydrolysis

$0.34 \pm 0.06$

Acylphosphatase-

treated labeled

membrane
$2 \mathrm{U} / \mathrm{mg}$
$0.43 \pm 0.05$
$5 \mathrm{U} / \mathrm{mg}$
$0.61 \pm 0.09$
$10 \mathrm{U} / \mathrm{mg}$
$0.80 \pm 0.12$

Labeled membranes ( $1 \mathrm{mg}$ protein) were incubated in $0.150 \mathrm{M}$ Tris- $\mathrm{HCl} \mathrm{pH}$ 7.2 at $37^{\circ} \mathrm{C}$ with varying amounts of acylphosphatase from 2 to 10 units per mg membrane protein (final volume:l $\mathrm{ml}$ ). Results are means $\pm \mathrm{S} . \mathrm{E}$. of five experiments with different membrane preparations. All the changes in ${ }^{32} \mathrm{P}$ release induced by acylphosphatase addition were statistically significant $(p<0.05)$. 
As shown in Table 1 , the release of phosphate, net of spontaneous hydrolysis, rose significantly with the increase inacylphosphatase membrane protein ratio. This hydrolytic effect was predictable (given the catalytic properties of our enzyme and the acylphosphate nature of the intermediate) all the more so since the literature has already reported similar effect of acylphosphatase on the acylphosphorylated intermediates of other transport ATPase, such as brain $\left(\mathrm{Na}^{+}-\mathrm{K}^{+}\right)$-ATPase (16) and sarcoplasmic reticulum $\mathrm{Ca}^{2+}$-ATPase (17). However, it is noteworthy that the enzymatic hydrolysis of EP occurred to a considerable extent with acylphosphatase amounts that fall in the physiological range.

In order to kinetically characterize the acylphosphatase effect we incubated a fixed amount of this enzyme ( 5 units) with variable amounts of P-labeled membranes and measured the initial velocity of dephosphorylation as a function of the phosphoenzyme concentration.

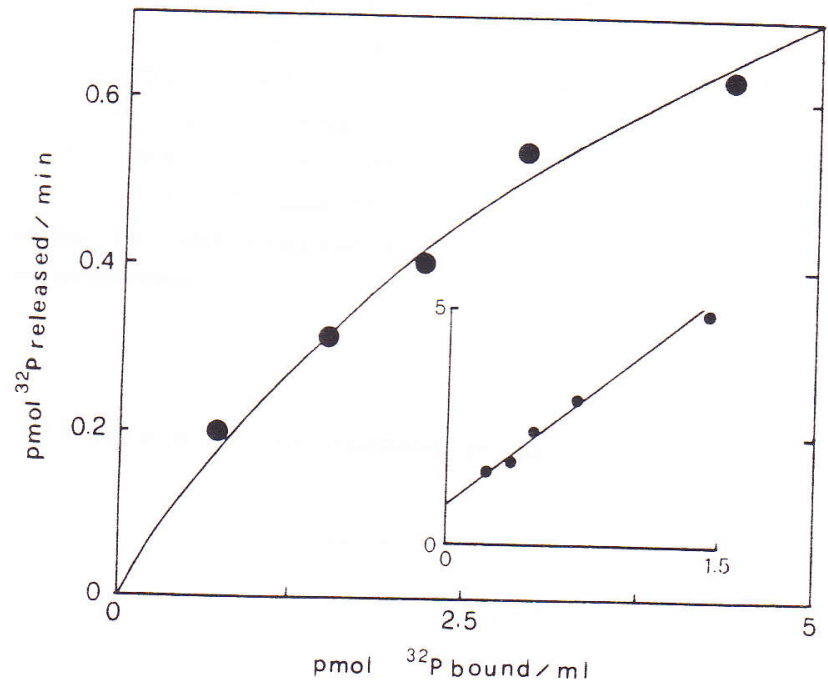

Fig. 2. Initial rate of $\mathrm{Ca}^{2+}$-ATPase intermediate dephosphorylation by acylphosphatase. 5 units of acylphosphatase were incubated in 0.150 $M$ Tris-HCl $\left(\mathrm{pH} 7.2\right.$ at $\left.37^{\circ} \mathrm{C}\right)$ with differing amounts of labeled membranes. EP concentration in the medium was expressed as pmol $\mathrm{P}$ bound $/ \mathrm{ml}$. Phosphate release was measured at two min intervals for $10 \mathrm{~min}$ and the initial rate of hydrolysis was estimated by calculating the first derivative value at zero time of the curve that describes the phosphate release, net of spontaneous hydrolysis, as a function of time. Each point represents the mean value of four determinations. The inset shows the double reciprocal plot of the data shown in the Figure.

In these conditions (Fig. 2) we observed that the initial rate of enzymatic dephosphorylation rose with the increase in EP concentration along a hyperbolic curve whose parameters were $\mathrm{K}_{\mathrm{m}}=3.41 \pm 1.16$ (S.E.) $\mathrm{nM}$ and $v_{\max }=1.19 \pm 0.207$ (S.E.) $\mathrm{pmol}^{32} \mathrm{P}$ released $/ \mathrm{min}$. The very low $\mathrm{Km}$ value that we found for acylphosphate hydrolis suggests a high affinity in 
this enzyme for EP, which seems to be consistent with the small number of $\mathrm{Ca}{ }^{2+}$-ATrase units, these latter only accounting in human RBC membranes for about $0.1 \%$ of total protein (12).

Effect of acylphosphatase on erythrocyte membrane $\mathrm{Ca}^{2+}$-ATPase

To see if the above action on the acylphosphorylated intermediate resulted in modified functional properties in $\mathrm{Ca}^{2+}-\mathrm{ATPase}$, we investigated the effect of acylphosphatase addition on the rate of $\mathrm{Ca}^{2+}$ dependent RBC membrane ATP hydrolysis. The mean value of basal $\mathrm{Ca}^{2+}$ -ATPase activity in our membrane preparations ranged from 109 to $150 \mathrm{nmol}$ of ATP split/h per mg membrane protein, a value which is close to that obtained by Thakar (18). When added to the assay medium in concentrations that ranged from 0.5 to 10 units per mg membrane protein, acylphosphatase significantly increased the rate of RBC membrane ATP hydrolysis. The increase depended on the amount of acylphosphatase added and maximal stimulation (about two fold over basal value) was observed at 2 units/mg membrane protein (Tab. 2). The effect of acylphosphatase was cumulative with that of calmodulin since $\mathrm{Ca}^{2+}$-ATPase activity observed with optimal calmodulin concentration was further enhanced by the addition of acylphosphatase (Tab. 3). The stimulatory effect of acylphosphatase in the presence of calmodulin was similar to that observed when this enzyme alone was added to the membranes.

Table 2. Effect of Exogenous Acylphospatase on Erythrocyte Membrane $\mathrm{Ca}^{2+}-$ ATPase

$\mathrm{Ca}^{2+}-$ ATPase activity

units/mg membrane protein nmol/h per mg membrane protein

A
0
0.5
1.0
1.5
2.0
5.0
10.0

$109 \pm 11$

$134 \pm 16+25$

$145 \pm 15+36$

$157 \pm 18+48$

$213 \pm 23+104$

$208 \pm 22+99$

$201 \pm 19+92$

Results are means \pm S.E. of six determinations performed on differing membrane preparations. A represents $\mathrm{Ca}^{2+}-\mathrm{ATPase}$ with acylphosphatase. $\triangle \mathrm{A}$ indicates the change in $\mathrm{Ca}^{2}+\mathrm{ATPase}$ with acylphosphatase compared to basal activity. Changes in $\mathrm{Ca}^{2+}$-ATPase activity observed with increasing amounts of acylphosphatase were statistically significant $(p<0.01$ by the one-way analysis of variance). 
Table 3. Effect of the Simultaneous Calmodulin on $\mathrm{Ca}^{2+}$-ATPase

units/mg membrane protein
0
1.0
1.5
2.0
2.5

nmol/h per mg membrane protein

$\begin{array}{ll}249 \pm 31 & \\ 291 \pm 35 & +42 \\ 301 \pm 38 & +52 \\ 348 \pm 41 & +99 \\ 337 \pm 39 & +88\end{array}$

Results are means \pm S.D. of six assays performed with different membrane preparations. In all assays calmodulin was added at $40 \mathrm{ng} / \mathrm{ml}$ (optimal $\mathrm{Ca}^{2+}$-ATPase without acylphosphatase. concentration of acylphosphatase difference observed with increasing the one-way analysis of variance).

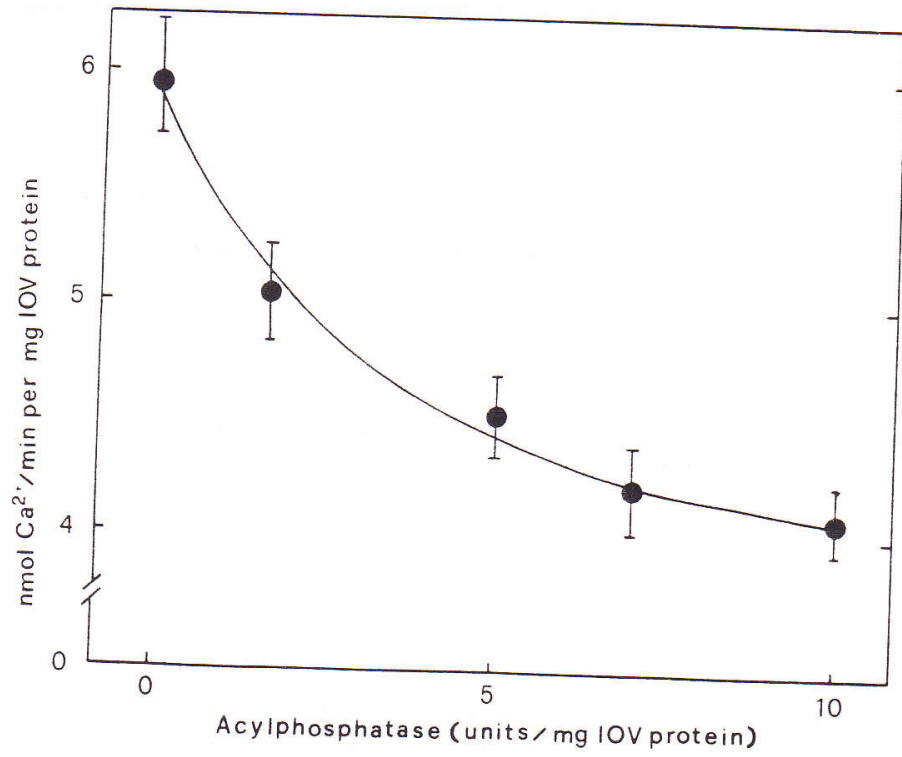

Fig. 3 . Effect of acylphosphatase on $\mathrm{Ca}^{2+}$ transport into RBC membrane inside-out vesicles. $\mathrm{Ca}^{2+}$ uptake into IOVs was measured at 4 min intervals for $16 \mathrm{~min}$ by a rapid filtration technique using $0.6 \mu$ pore Sartorius membrane filter. Each point represents the mean \pm S.E. of four determinations. Changes observed with differing amounts of acylphosphatase were statistically significant ( $p<$
0.01 by one way analysis of variance). 
Effect of acylphosphatase on $\mathrm{Ca}^{2+}$ transport into $\mathrm{RBC}$ membrane inside-out vesicles (IOVs)

Acylphosphatase also affected $\mathrm{Ca}^{2}+$ transport across erythrocyte membranes, but this effect was of opposite type compared with that on the rate of ATP hydrolysis. In fact comparable amounts of acylphosphatase decreased the rate $\mathrm{Ca}^{2+}$ transport into inside-out $\mathrm{RBC}$ vesicles and more markedly so with higher enzyme amounts. Maximal inhibition of $\mathrm{Ca}^{2+}$ transport was obtained with $10 \mathrm{units} / \mathrm{mg}$ membrane protein and resulted in a decrease of about $30 \%, 4.09 \pm 0.15$ (S.E.) nmol/min per $\mathrm{mg}$ IOV protein, with respect to basal value, $5.98 \pm 0.27$ (S.E.) nmol/min per $\mathrm{mg}$ IOV protein (Fig. 3).

\section{CONCLUSION}

From the results here reported acylphosphatase appears to have an uncoupling effect on the erythrocyte $\mathrm{Ca}^{2+}$ pump. This was confirmed by the diminished $\mathrm{Ca}^{2+} / \mathrm{ATP}$ ratio that we found in the presence of acylphosphatase when we measured in the same the rate of $\mathrm{Ca}^{2+}$ uptake and of ATP hydrolysis by IOVs. This value decreased from 2.01 to 0.91 in the presence of acylphosphatase at a concentration of 10 units/mg IOV protein. As regards the mechanism underlying acylphosphatase action, it is generally accepted that the operation of $\mathrm{RBC}$ membrane $\mathrm{Ca}^{2+}$ pump proceeds through the sequence of elementary reactions reported in the Scheme (12)

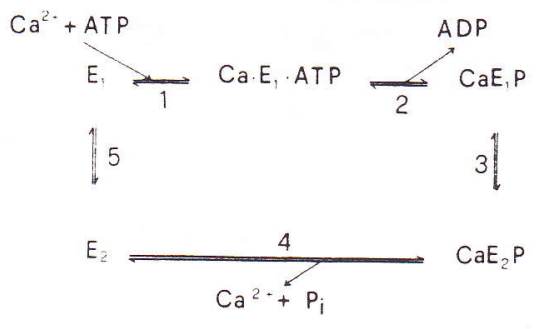

$\mathrm{Ca}^{2+}$-ATPase exists in two conformers, $\mathrm{E}_{1}$ and $\mathrm{E}_{2} \cdot \mathrm{Ca}^{2+}$ and ATP binding to $\mathrm{E}_{1}$ leads to the $\mathrm{Ca}^{2+}-\mathrm{E}-\mathrm{ATP}$ complex. Phosphorylation by ATP results in the conversion of $\mathrm{Ca}^{2+}-\mathrm{E}_{1}-\mathrm{P}$ to $\mathrm{Ca}^{2+}-\mathrm{E}_{2}-\mathrm{P}$. After the release of $\mathrm{Ca}^{2+}$ and dephosphorylation $\mathrm{E}_{1}$ is converted into $\mathrm{E}_{2}$ and the cycle closes.

We propose that acylphosphatase-induced hydrolysis of the phosphoenzyme intermediate occurs before $\mathrm{Ca}^{2+}$ transport has taken place, thereby short circuiting the system and giving rise to an accelerated ATP hydrolysis with concomitant inhibition of $\mathrm{Ca}^{2+}$ pumping. The effects above described suggest an additional mechanism of energy wasting, which given the higher acylphosphatase levels observed in mature RBCs with respect to younger erythrocytes - might increase with ageing contributing to the age-dependent decline of the energetic potential of these cells. 


\section{REFERENCES}

1. G. Ramponi, C. Treves and A. Guerritore, Hydrolytic activity muscle acylphosphatase on 3-phosphoglyceroylphosphate, Experienti 23:1019 (1967).

2. G. Ramponi, F. Melani and A. Guerritore, Azione dell'acilfosfatasi d muscolo su carbamilfosfato, G. Biochim. 10:189 (1961).

3. A. Berti, M. Stefani, G. Liguri, G. Camici, G. Manao and G. Ramponi, Acylphosphatase action on dicarboxylic acylphosphates, Ital. J. Biochem. 26:377 (1977).

4. G. Cappugi, G. Manao, G. Camici and G. Ramponi, The complete aminoacid sequence of horse muscle acylphosphatase, J. Biol. Chem. $255: 6868$ (1980).

5. G. Camici, G. Manao, G. Cappugi, A. Berti, M. Stefani, G. Liguri an G. Ramponi, The primary structure of turkey muscle acylphosphata Eur. J. Biochem. 137:269 (1983).

6. G. Manao, G. Camici, G. Cappugi, M. Stefani, G. Liguri, A. Berti and Ramponi, Rabbit skeletal muscle acylphosphatase: the aminoaci sequence of form Ral, Arch. Biochem. Biophys. 241:418 (1985).

7. G. Manao, G. Camici, A. Modesti, G. Liguri, A. Berti, M. Stefani, Cappugi and G. Ramponi, Human skeletal muscle acylphosphatase. Th primary structure, Mol. Biol. Med. 2:369 (1984).

8. G. Liguri, G. Camici, G. Manao, G. Cappugi, P. Nassi, A. Modesti G. Ramponi, A new acylphosphatase isoenzyme from human erythrocyt purification, characterization and primary structure, Biochemist 25:8089 (1986).

9. G. Liguri, P. Nassi, D. Degl'Innocenti, E. Tremori, C. Nediani, A. Bet and G. Ramponi, Acylphosphatase levels of human erythrocytes durit cell aging, Mech. Ageing Dev. 39:59 (1987).

10. D. Degl'Innocenti, A. Berti, G. Liguri, M. Stefani and G. Ramponi Determinazione dei livelli di acilfosfatasi di tipo eritrocitario tessuti umani con metodo ELISA, $32^{\circ}$ Congresso Nazionale della Soci Italiana di Biochimica, Messina, 28 Settembre 1986, Riassunti de Simposi e Poster, p. 400.

11. G. Ramponi, C. Treves and A. Guerritore, Continuous optical assay 0 acylphosphatase with benzoylphosphate as substrate, Experienti 22:705 (1966).

12. N. P. Adamo, A. F. Rega and P. J. Garrahan, Pre-steady-state phosphorylation of the human red cell $\mathrm{Ca}^{2+}$-ATPase, J. Biol. Chem. 263:17548 (1988).

13. F. B. Davis, P. J. Davis and S. D. Blas, Role of calmodulin in thyro: hormone stimulation in vitro of human erythrocyte $\mathrm{Ca}^{2+}-\mathrm{ATPa}$ activity, J.Clin. Invest. 71:579 (1983).

14. K. K. W. Wang, A. Villalobo and B. D. Roufogalis, Activation of the Ca -ATPase of human erythrocyte membrane by an endogenous $\mathrm{Ca}^{2+}$-depende neutral protease, Arch. Biochem. Biophys. 260:696 (1988).

15. M. G. Luthra, R. P. Watts, K. L. Scherer and H. D. Kim, Calmodulin: an activator of human erythrocyte $\left(\mathrm{Ca}^{2+}+\mathrm{Mg}^{2+}\right)$-ATPase phosphorylatio Biochim. Biophys. Acta 633:299 (1980). 
16. L. E. Hokin, P. S. Sastry, P. R. Galsworthy and A. Yoda, Evidence that a phosphorylated intermediate in a brain transport adenosine triphosphate is an acylphosphate, Proc. Natl. Acad. Sci.U.S.A. 54:177 (1965).

17. M. Stefani, G. Liguri, A. Berti, P. Nassi and G. Ramponi, Hydrolysis by horse muscle acylphosphatase of $\left(\mathrm{Ca}^{2+}+\mathrm{Mg}^{2+}\right)$-ATPase phosphorylated intermediate, Arch. Biochem. Biophys. 208:37 (1981).

18. J. H. Thakar, Method for the preparation of human erythrocyte membrane with low basal calcium ATPase, responsive to stimulation, Anal. Biochem. 144:94 (1985). 